\title{
PJIEE
}

Premise : Journal of English Education and Applied Linguistics

https://fkip.ummetro.ac.id/journal/index.php/english

Nuningtyas, Athiyallah \& Pratolo

\section{COMPARATIVE ANALYSIS OF THE USAGE OF WHATSAPP AS A LEARNING APPLICATION IN ENGLISH DURING THE COVID-19 PANDEMIC IN ELEMENTARY SCHOOL AND JUNIOR HIGH SCHOOL STUDENTS}

\author{
by \\ Rinda Nuningtyas \\ UNIVERSITAS AHMAD DAHLAN YOGYAKARTA \\ rindanuning12@gmail.com \\ Arina Athiyallah \\ UNIVERSITAS MUHAMMADIYAH SURAKARTA \\ arinaathiyallah48@gmail.com \\ Bambang Widi Pratolo \\ UNIVERSITAS AHMAD DAHLAN \\ bambang.pratolo@pbi.uad.ac.id
}

\begin{abstract}
:
During the Covid-19 pandemic, there was a very significant change in student teaching and learning methods. The government policy requires that almost all activities including learning activities at school be eliminated and replaced with online schools. One of the most used applications for learning in this pandemic era is WhatsApp. The general objective of this research is to conduct a comparative study on the use of the WhatsApp application as a learning application during the Covid-19 pandemic in elementary and junior high school students in English. While the specific purpose of this research is to find out the strengths and weaknesses as well as the constraints of using WhatsApp as a learning application. The research method used is through field observations using qualitative descriptive methods and also interview techniques to several elementary and junior high school students in the research environment. This is interesting to research further based on direct observations of researchers on the use of WhatsApp on school students directly. This study assumes that the advantages and disadvantages of the learning process using WhatsApp will be found for both elementary school students and junior high school students. That elementary school finds difficulty in using WhatsApp for learning. Because some of the elementary students are still not fluent in reading. Junior high school learners assume that learning by WhatsApp is efficient but still not comparable to face-to-face meetings. The research implications are as follows: that the students would be able to learn easily by using WhatsApp as a learning application. The teacher Would find another method that enhances the understanding of the students besides using WhatsApp by necessity.
\end{abstract}

Keywords: Learning Application; Whatsapp Usage; Elementary Students; Junior Students, English learning.

\section{INTRODUCTION}

Online media is an alternative in the world of education at this time when the whole world is facing the Covid-19 pandemic (Abidah, 2020). Agree with what has been stated by Watie 
(2011: 69) that the emergence and development of the internet can change new ways of communicating in the community. The majority of Indonesians use WhatsApp as one of the instant messenger platforms to communicate with other people. Napratilora et al., (2020) and Gon \& Rawekar, (2017) mention that Whatsapp makes it easy to interact with other people and a convenient tool for teaching and learning through messages, pictures, audio, documents, and having group discussions.

Firman dan Rahman (2020) stated that distance learning carried out was lacking in terms of interaction, teachers were unable to directly monitor the learning process and limited ability to receive material delivered online with the WhatsApp application. Online learning has a direct impact on students including the availability of inadequate facilities and infrastructure, differences in the atmosphere when studying in class and studying at home so that it affects student learning motivation, and the tendency of students' visual or written learning styles (Satrianingrum \& Prasetyo, 2020).

According to Kheryadi, (2018), the WhatsApp application is the most widely used application to communicate with others, reaching $82 \%$ of users. Related to online media used by WhatsApp by elementary and junior high school students, the researchers intend to conducting research in order to obtain accurate data and information related to how students use WhatsApp as a learning media during pandemic Covid-19, what are the obstacle that occurs in the usage of WhatsApp as a learning medium and what are the solutions to overcome the obstacles in the implementation of online learning by using WhatsApp in the school.

Based on a preliminary study by researchers, learning using WhatsApp in elementary school is considered more difficult to convey because it is not optimal in delivering material by teachers and elementary students cannot read fluently. While learning using WhatsApp in junior high school students can run smoothly because junior high school students can respond well so that communication goes both ways and can be said to be effective even though it feels different from face-to-face meetings. The effectiveness of using the WhatsApp application as a medium for learning English cannot be separated from its function and role. First, as a means of education, namely WhatsApp as a tool to transform teaching materials to students as well as a tool to control students' speech, attitudes and character. Second, as a means of evaluation, which includes evaluation of activities, evaluation of test scores, and evaluation of student attitudes during the learning process at school. Third, as a means of connecting information both from the school to students, the school to parents, and vice versa. Using WhatsApp to forward information is very helpful and is more comprehensive. Fourth, as a means of consulting 
services and establishing friendships, WhatsApp is used as a consultation medium through messages. The obstacle that is found in the WhatsApp application as one of the learning methods is the active discussion of group members who are students. There are only a few students who actively participate in learning through WhatsApp groups.

During the current pandemic, SD IT Bina Ilmu and SMP 2 Taman chose to use the WhatsApp application as a learning medium because the WhatsApp application has various functions, including being able to send messages, voice messages (voice notes), group messages, send photos, documents. and videos. However, learning English using WhatsApp is not always effective for every student. This results in students being indifferent and unresponsive during the learning process and ultimately parents are overwhelmed during online schooling.

Basar, A.M. (2021) stated that learning during the Covid-19 pandemic has resulted in extraordinary changes, as if all levels of education including elementary school (SD) and junior high school (SMP) are 'forced' to transform to adapt suddenly to learning from home through online media. This is certainly not an easy thing, because it is not fully ready. The problem in the world of education is that the learning process is not yet uniform, both the standard and the quality of the desired learning outcomes. Therefore, positive, creative and innovative thinking can help overcome various problems in the distance learning process by applying fun online learning media, resulting in quality learning outcomes. Distance learning using online media expects students to be able to take part in learning to the maximum (Jaelani et al, 2020).

According to Basar, A.M. (2021), the online learning process during the COVID-19 pandemic should still be able to accommodate the learning needs of students to develop talents and interests according to their level of education. However, to achieve this requires the readiness of educators, an appropriate curriculum, the availability of learning resources, and support for stable devices and networks so that communication between students and educators can be effective. The current condition of online learning cannot be called ideal because there are still various obstacles faced. Since March 16, 2020, the Indonesian Child Protection Commission (KPAI) has received around 213 complaints from both parents and students regarding the implementation of distance learning (Kompas, 2020). The complaint related to: first, the assignment is too heavy with a short time. Second, the many tasks of summarizing and copying from books. Third, study hours are still rigid. Fourth, the limited quota for participating in online learning. And fifth, some students do not have personal devices so that they have difficulty taking online exams. 
This obstacle is also a challenge in the implementation of online learning considering that the implementation of online learning is a must so that educational activities can still be held in the midst of the current Covid-19 pandemic emergency (Basar, A.M., 2021). Barriers faced in the implementation of online learning, among others, relate to the readiness of human resources, the lack of clear directions from the local government, the absence of an appropriate curriculum, and limited facilities and infrastructure, especially technology support and internet networks. The readiness of human resources including educators, students, and parental support is the most important part in the implementation of online learning (Arifa, 2020).

According to (Ermayulis, 2020) mention online learning using various online applications while Basilaia, Dgebuadze, Kantaria, and Chokhonelidze (2020) mention that it is divided by two types of online learning which are synchronous and asynchronous. Synchronous happen when teachers and learners meet in a session at a predetermined time, for example, streaming video calling, zooming, and audio calling. However asynchronous is when the teachers have uploaded all the materials and learners can access them at any time they need. moreover,

According to Susilawati \& Supriyatno, (2020) states that WhatsApp messenger enhances students' learning motivation and trigger the occurrence of study group which leads to information sharing in the learning process. Students develop positive opinions towards the usage of WhatsApp in their courses due to effective learning ways by sending images, videos that attract students' attention, although few students have express adverse opinions regarding the timing of some posts and redundant posts within the group. As the result, the usage of WhatsApp in learning processes is encouraged as a supportive technology Cetinkaya, (2017).

Based on the background that has been mentioned, the researcher is interested in identifying more deeply about how the online learning process uses the WhatsApp in English media subject in Elementary School and Junior High School Students. It is hoped that the results of this study can provide benefits and can help educators or teachers to consider what learning media are suitable for use in the teaching and learning process. Hence, this research purposes exploration:

1. how students use WhatsApp as a learning medium during the Covid-19 pandemic?

2. what are the obstacles that occur in the use of WhatsApp as a learning medium?

3. what are the solutions to overcome the hindrances in the implementation of online learning by using WhatsApp in the school? 


\section{METHODS}

\section{Design}

The design of this study is a qualitative research which is descriptive in which the data is collected in the form of words (Bogdan and Biklen, 1982). This study is conducted in Elementary School (SDIT Bina Ilmu) and Junior High School (SMPN 2 Taman). The focus was on the student's perception upon the using of WhatsApp application as a media during covid-19 pandemic, types of problems of using WhatsApp and how the students overcome their problem respectively.

\section{Participant}

Participants of this study were 4 students at SDIT Bina Ilmu Elementary School grade 5 and 4 students at SMPN 2 Taman Pemalang junior high school as subjects of this study who took English subjects. They answered all interview questions asked by the interviewers. Data was collected by semi-structured interviews. This type of interview was chosen because it tends to be easy to use and can provide free space for researchers to probe the data. Thus, the mode of interview was under a consideration of avoiding risk of covid-19 outbreaks (Turmudi, 2021).

\section{Data Collection}

In this research, researchers used interviews as a data collection technique. Researchers give interview questions to participants regarding the usage of WhatsApp in the learning process among both groups students elementary and junior high school students in English subject by having video calling them. After getting the data, the researcher analyzed the data. In this case, the researcher reduces, displays, and concludes the data (Miles et al., 2014). Researchers ignore and reduce irrelevant data by providing codes and notes. Then, to present detailed data, the researcher chose the appropriate data related to the usage of WhatsApp as a learning application during the covid-19 pandemic in elementary school and junior high school students.

\section{Data Analysis}

The data analysis technique is coded, categorized, clustered under the theme which is analyzed in the form of words from the interview results. The present study conducted thematic 
analysis that was originally developed by Hokhar, Pathan, Raheem, dan Abbasi (2020). This analysis examines the data to identify the common themes such as topic, ideas, and pattern of meaning that come up repeatedly. There are six steps in order to identify responses into themes; familiarization, coding, generating themes, reviewing themes, defining and naming themes and writing up. The whole citation model employed a manual model by copying references from scholar google (Turmudi, 2020, p.59).

\section{FINDINGS AND DISCUSSION}

Based on the interview of participants' responses we were able to divided into three main themes; the usage of Whatsapp as a learning application during the Covid-19 Pandemic, The hindrances of using whatsapp as learning application during Covid 19 pandemic, and The solutions to overcome the hindrances during online learning by Whatsapp application.

\section{Theme 1: How students use WhatsApp as a learning medium during the Covid-19 pandemic?}

Whatsapp is a user-friendly learning application for elementary students because of its features. All of the respondents are already familiar with this application and the features such as video calls, voice notes, file transferring that support learning processes. "Usually we use WhatsApp, using voice note, text chat, sometimes video calls when speaking in English class, sometimes we send our assignment and we have to take a photo using file transferring". Meanwhile the remaining three respondents respond the same thing that WhatsApp is rich with its features thus this application is preferable in learning.

Apart from that, the learning implementation system using WhatsApp is systematically organized by the school. "Firstly, the teacher will share the link for attendance, before the class begins using a google form, after that we wait until all is done, then we pray and we begin the lesson”. Nevertheless, other respondents mention that her school has a different tentative "we submit assignments from the teacher and it is considered as attendance".

Whereas, junior high school respondents encounter different experiences as elementary respondents. WhatsApp is the easiest application to use by junior high school students. With its features, WhatsApp has many advantages for online teaching and learning activities, such as easily sending text messages, videos, and photos to support learning. Files can be shared easily, this allows the use of a variety of study materials. Starting from ebooks, PPT, documents, and so on. This was noted by all respondents junior high school students: 
"Features video call, telephone, send pictures, text. Most often text messages to communicate with teachers either in the group or private messages."

Further findings were that students state that online learning media using WhatsApp is easy to use and effective for online learning. This is revealed in the following except by students 2: "No need to download like Google meeting because the features are complete. Facilitate communication when you want to communicate with the teacher, such as asking questions about learning problems, you can learn online through chat or video calls too. Then if the link is absent, there is no need to use another application so it's easy." The data above illustrates the advantages of using WhatsApp for online learning. It shows the advantages experienced by students while using WhatsApp as a learning application during the Covid-19 pandemic. Respondents depict that using WhatsApp as a learning medium is tougher than offline sessions due to lack of benefit in the learning process, ineffective, and boring. All respondents mention the same thing as "Usually, English lesson takes 4 hours every week and in every meeting we have to wait for others to response what teacher says while waiting it is so boring sometimes we play games and chit chat to friends"

The WhatsApp application is very challenging for junior high school students as most of the students cannot understand the expectations of the course and struggle to stay motivated due to the lack of direct interaction. As one student said: "It's okay. Not happy but not lazy either." The student sounds demotivated during the WhatsApp discussion. A student indicated that they were happy to study online using the WhatsApp platform, as said by student 2: "I feel happy because I don't have to download other applications. Just open WhatsApp, everything will appear, there is already a file link and that's all. So it's very easy. Even though I prefer face-to-face, I see the teacher directly, so I understand better." This shows that it is true that WhatsApp is an application that is friendly for online learning, but still in terms of understanding it is different from class contact time. WhatsApp communication can never compare to class contact time. The students' expressions seem to indicate that online interaction can hardly replace the importance of physical teaching. Face-to-face learning is more acceptable than online learning in terms of social presence, social interaction, and satisfaction. However, this study argues that there is no significant perception of online learning and face-to-face learning. Although face-to-face learning is felt to be more satisfying, many choose online learning over face-to-face classes for convenience and ease of time. Therefore, instructors must have a concrete understanding of theory and 
practice to be effective, both in online learning and face-to-face learning to attract class participation.

\section{Theme 2: What are the obstacles that occur in the use of WhatsApp as a learning medium?}

Internet connection is the main challenge for elementary students in online learning using WhatsApp. Its disruption delays the information given by teachers due to slow internet connection has been brought to miscomprehend to the respondents in class. " internet signal troubles and sometimes I need to add data to the internet so I can send my assignment as soon as possible." meanwhile "we prefer to have face to face session rather than online because we often do not understand about the lesson given and too many assignments". Apart from that, " using WhatsApp make me spend my data internet a lot"

All junior high school students did not have problems with learning media. The majority of respondents use smartphones when accessing online learning. Respondents have no problems regarding the quality of the media they use. However, one respondent complains that sometimes there is a power outage in his place during the hours when online learning is being carried out, thus disrupting the ongoing learning process. "Internet connection, when the power fails it's usually an error connection. "student 2.

Meanwhile, almost all respondents complained about the slow internet network in their place. Sometimes the network is error or disconnected when participating in online learning, and the quota often runs out quickly. Only a few respondents do not complain about internet network problems because their home has WiFi. "Signal, when the power fails during lesson time, the wi-fi turns off and sometimes I don't have a quota either. "student 4 Junior high school students have problems downloading the material given because the memory is full. The obstacle faced when learning online using the application is the file is sometimes too large. "Sometimes I can't open the file because the file is too big." Students 3

Theme 3: What are the solutions to overcome the hindrances in the implementation of online learning by using WhatsApp in the school?

The solutions to the hindrance using WhatsApp faced by elementary students according to respondents are by upgrading the internet connection through wifi, data internet, although the government has provided assistance to students and if the students are blurred with subjects they actively question every single lesson that is not understood. "I use internet data because it is faster than I use wifi, and if I do not understand what teacher says during english online class I will ask her in direct message" "if my internet signal troubles, I will use 
my parents' phone or I buy more internet data and if I do not understand teacher, I will ask her."

To overcome problems regarding signals by junior high school students, they refresh the cellphone first then tethering from their parents. Regarding quotas, students must go out to buy quotas. For cell phone memory, students try to clean up files that are not important in their cellphones. If the students really can't open the file, the final solution is to come to school and meet the teacher. The teacher will give a printout of the material. "Restart the phone. If I can't open the assignment file, I can come to school, make an appointment with the teacher. If my quota runs out during class hours, I will go to the counter to buy quota. If the signal is difficult, I will ask my parents to tethering the internet connection." Student 3 Based on the responses of the participants they are aware of the several hindrances that occur during teaching-learning that rely on online applications such as Whatsapp with the biggest issue of internet connectivity. Thus, students come up with solutions to the hindrance by fixing the connectivity speed and additional expenses in order to provide more internet data.

The learning process integrating WhatsApp application is effective for learning and teaching. Based on the result of the present research, the WhatsApp application for learning activities can be a powerful and effective tool for junior high school students. Gillingham et al., (1999) stated that instant messaging is considered an effective tool for learning and teaching through social interactions. In the domain of habits and usability, we note that WhatsApp instant messaging is an easy-to-use interface for students, many of whom are familiar with its use in everyday life. The study shows that a majority of respondents felt that social networking tools based on WhatsApp application for learning activities can help with learning and knowledge sharing. Chan, (2005) stated that instant messaging for academic purposes using WhatsApp provides students with opportunities to interact and construct and share knowledge.

Using social media or mobile devices brings its benefit in terms of the easiness of accessing relevant information, materials, and course content. It can be seen from the responses above that Whatsapp is used as a medium of online learning as it is a simple and convenient tool for obtaining information. Zounek \& Sudicky, (2013) mention that online technologies let students and teachers derive information regarding the course easily due to simple tools. Apart from that, Gon \& Rawekar, (2017) teachers' availability of consulting hours with their students. 
Teachers set a schedule and a general guideline in order for elementary students to follow. Learning enhanced by online technologies sometimes can be ineffective for elementary students due to lower self-regulation to the pace of their learning and progress according to their skills and abilities. In contrast, junior high school students are independently capable of personalizing time management, and schedule. Students in the case study sample used WhatsApp frequently in their daily lives and therefore found the technology easy to use. WhatsApp instant messaging allows students to receive messages instantly. It is an interactive tool that facilitates the rapid exchange of ideas.

The result of this research also supported by Sawant \& Chari (2021) technology contributes to technology addiction so that stress arising out of it with overload information also, interpersonal communication among the students will be the most concerning issue due to lack of face to face communication and this could affect their mental state also. Research done by Gon \& Rawekar, (2017) agree with the current study that the disadvantages of whatsapp as a learning tool are message flooding, time consuming and eye strain.

The hindrance of using WhatsApp as an online medium learning experience during the online learning process includes unstable signal strength, inadequate internet data packets until the cell phone memory is full. In addition to that, (Gon \& Rawekar, 2017) suggest that Wifi connection will be economically effective when enabling to a Wifi in the school.The use of online applications is adjusted to what material will be delivered, on material that is only in the form of theory, the teacher will be delivered using the Whatsapp application in the form of PowerPoint or a summary of the material, then it will be evaluated with practice questions using Google Form. Although there are various obstacles, online learning is still carried out in junior high schools according to their respective classes and online learning in junior high schools can be said to be effective according to the results of research and the results of the data collected.

Based on a study conducted by Sawant \& Chari, (2021) WhatsApp is an effective tool for ICT in Higher Education but it must be used wisely and cautiously by both the teachers and the students.

\section{CONCLUSION AND IMPLICATION}

The conclusions in this study are taken from the findings and discussions presented in the previous section, it can be concluded that the analysis of the usage of WhatsApp as a learning application during the covid-19 pandemic in elementary school and junior high 
school students in English subject is divided into three themes which are the usage of WhatsApp as a learning medium during the Covid-19 pandemic, the hindrances/obstacles of using whatsapp as a learning medium tool, and the solutions to overcome the hindrances during online learning by Whatsapp application.

Accordingly, some implications are identified. One of them is theoretical implication. The selection of online learning tools determine students' learning process especially in understanding the materials given by their teachers. For English lessons, elementary school students observe difficulty in using WhatsApp for learning. As a result of the elementary students' reading fluency and proficiency. Whereby, junior high school students learning English assume that learning by WhatsApp is efficient but still not comparable to face-to-face meetings.

Another one is practical implications. Schools and teachers are encouraged to provide integrated and comprehensive online learning tools in order for students to easily operate or use it so that during the learning process, students are expected to obtain better understanding during online classes.

\section{ACKNOWLEDGEMENT}

The authors thank for the collaboration between two universities which are Ahmad Dahlan University (UAD) and University Muhammdiyah Surakarta (UMS). Also, Assoc. Prof. Dr. Eny Purwandari as the Head of Department of Master of Psychology UMS and Drs. Akmal M.Hum., Ph.D. who provided insight, guidance, and expertise that greatly assisted the research and those who brought their contributions to this research paper.

\section{BIO-PROFILE}

Rinda Nuningtyas holds a Bachelor's degree in English Teaching from Ahmad Dahlan University Yogyakarta and is now studying her Masters in English Teaching at Ahmad Dahlan University Yogyakarta. Currently, she is working as an Educator at STIT Language Center. He is passionate about teaching. Corresponding email: rindanuning12@gmail.com

Arina Athiyallah graduated from International Islamic University Malaysia with her bachelor's degree in human sciences majoring in Psychology and pursue her master's degree in Muhammadiyah University of Surakarta specializing in psychology. Apparently, she is working as English lecturer and working as a psychology consultant Student Counseling Center 
in Pemalang college of Education Sciences. A highly dedicated and passionate psychology graduate and highly committed Muslim psychologist to be gain expertise in psychological counseling and mental health awareness. Corresponding email: arinaathiyallahofficial@gmail.com

Bambang Widi Pratolo holds doctoral degree in TESOL from Monash University, 2015. He has worked with Monash University in Australia (2009-2015) and is currently a senior lecturer in the University of Ahmad Dahlan, Indonesia. His research areas include teachers' professional beliefs and practices, student voices, learning strategies, and innovative pedagogy. With nearly 30 academic publications and rich experiences in consultation work, he has taken leading roles in organising many international conferences in English language education as well as has served as a senior advisor and manager for several peer-reviewed academic journals worldwide. Corresponding email: bambang.pratolo@pbi.uad.ac.id 


\section{REFERENCES}

Abidah, A., Hidaayatullaah, H. N., Simamora, R. M., Fehabutar, D., \& Mutakinati, L. (2020). The impact of covid-19 to indonesian education and its relation to the philosophy of "merdeka belajar". Studies in Philosophy of Science and Education, 1(1), 38-49.

Arifa, F. N. (2020). Implementation Challenges of Learning From Home Policies in The Emergency of Covid-19. Social Welfare Division Info Singkat, XII, 7.

Basar, A.M. (2021). The Problems of Distance Learning During the Covid-19 Pandemic (Case Study at SMPIT Nurul Fajri - Cikarang Barat - Bekasi). Edunesia: Scientific Journal of Education, 2(1),208-218.

Bogdan, R. C., \& Biklen, S. K. (1982). Qualitative research for education: An introduction to theory and methods. Boston: Allyn and Bacon.

Cetinkaya, L. (2017). The Impact of Whatsapp Use on Success in Education Process. The International Review of Research in Open and Distributed Learning, 18(7), 59-74. https://doi.org/10.19173/IRRODL.V18I7.3279

Chan, L. (2005). WebCT Revolutionized E-learning. UBC Reports, 51(7),7 https://news.ubc.ca/2005/07/07/archive-ubcreports-2005-05jul07-webct/

Gillingham, M. G., Gillingham, M. G., \& Topper, A. (1999). Technology in Teacher Preparation: Preparing Teachers for the Future. Journal of Technology and Teacher Education, 7(4), 303-321.

Gon, S., \& Rawekar, A. (2017). Effectivity of E-Learning through Whatsapp as a Teaching Learning Tool. MVP Journal of Medical Sciences, 4(1), 19-25 https://doi.org/10.18311/MVPJMS/0/V0/I0/8454

Jaelani, A. K., Handayani, I. G. A. K. R., \& Karjoko, L. (2020). Development of tourism based on geographic indication towards to welfare state. International Journal of Advanced Science and Technology, 29(3s), 1227-1234.

Kheryadi, K. (2018). The Implementation of "WHATSAPP" as a Media of English Language Teaching. Loquen: English Studies Journal, 10(2), 1-14. https://doi.org/10.32678/LOQUEN.V10I2.685

Khokhar, S., Pathan, H., Raheem, A., \& Abbasi, A. M. (2020). Theory Development in Thematic Analysis: Procedure and Practice. Review of Applied Management and Social Sciences, 3(3), 423-433.

Miles, M. B., Huberman, A. M., Saldana, J., Huberman, M. a, Saldana, J., Huberman, A. M., ... Saldaña, J. (2014). Qualitative Data Analysis: A Methods Sourcebook. In Zeitschrift fur Personalforschung (3rd ed., Vol. 28). SAGE Publications. https://doi.org/January 11, 2016. 
Napratilora, M., Lisa, H., \& Bangsawan, I. (2020). Using WhatsApp as a Learning Media in Teaching Reading. Mitra PGMI: Jurnal Kependidikan MI, 6(2), 116-125. https://doi.org/10.46963/MPGMI.V6I2.129

Satrianingrum, A. P., \& Prasetyo, I. (2020). Persepsi Guru Dampak Pandemi Covid-19 terhadap Pelaksanaan Pembelajaran Daring di PAUD. Jurnal Obsesi : Jurnal Pendidikan Anak Usia Dini, 5(1), 633-640. https://doi.org/10.31004/obsesi.v5i1.574

Sawant, N., \& Chari, N. (2021). WhatsApp as an ICT Tool in Higher Education- a Survey During COVID Pandemic in the State of Goa. https://doi.org/10.20944/PREPRINTS202105.0160.V1

Susilawati, S., \& Supriyatno, T. (2020). Online learning through WhatsApp group in improving learning motivation in the era and post pandemic COVID-19. Jurnal Pendidikan: Teori, Penelitian, dan Pengembangan, 5(6), 852-859. http://journal.um.ac.id/index.php/jptpp/

Turmudi, D. (2020). English Scholarly Publishing Activities in the Industrial Revolution 4 . 0 : What, Why, and How ? ELTEJ, 3(1), 52-63. Retrieved from http://journal2.uad.ac.id/index.php/eltej/article/view/1890

Turmudi, D. (2021) Inovasi teknik pengambilan dan analisis data di era pandemic covid-19 dan kelaziman baru: tinjauan literatur in Perspektif covid-19 dalam kajian multidisipliner. Bandung: KODEPENA.

Watie, E. D. S. (2016). Komunikasi dan media sosial (communications and social media). Jurnal The Messenger, 3(2), 69-74.

Zounek, J., \& Sudicky, P. (2013). Heads in the Cloud: Pros and Cons of Online Learning. Conference: INTERNATIONAL CONFERENCE DisCo 2013: New Technologies and Media Literacy Education, 58-63.

https://www.researchgate.net/publication/311807840_Heads_in_the_Cloud_Pros_and _Cons_of_Online_Learning 